Etihad: Journal of Islamic Banking and Finance

Vol. 1, No. 1, Januari - Juni 2021: 37-50

\title{
ANALISIS KINERJA KEUANGAN PT. INDUSTRI JAMU DAN FARMASI SIDO MUNCUL TBK
}

\author{
Tiara Widya Antiksari \\ Institut Agama Islam Negeri Ponorogo, Indonesia \\ Email: tiara@iainponorogo.ac.id
}

\begin{abstract}
Corona virus has an impact on all sectors of the company, so companies must have effecient financial performance to be considered as a healty company. This study aims to analyze the financial performance of PT. Industri Jamu dan Farmasi Sido Muncul Tbk in year of 2016 to 2020 by using financial ratio analysis. This study uses the financial statement data 2020 and four financial ratio to make it more complete than previous studies. The research method which has been used to measure the financial performance at PT. Industri Jamu dan Farmasi Sido Muncul Tbk the financial ratio analysis which consists of liquidity ratio, solvability ratio, activity ratio and profitability ratio. The result of this research is based on the liquidity ratio which is proxy by current ratio and cash ratio, it has been found that the condition of the financial performance of the company is liquid. Solvability ratio which is proxy by debt ratio and debt to total equity ratio, it has been found that the condition of the financial performance of the company is good. Activity ratio which is proxy by fixed assets turnover and total assets turnover, it has been found that the condition of financial performance of the company is less efficient. The profitability ratio which is proxy by return on assets is good and return on invesment is less good. The ratio that indicates a good condition is liquidity ratio and solvability ratio.
\end{abstract}

Keywords: financial, liquidity, solvability,activity, profitability.

Abstrak: Virus corona berdampak pada semua sektor perusahaan, sehingga perusahaan harus memiliki kinerja keuangan yang efisien agar dapat dinilai sebagai perusahaan yang sehat. Penelitian ini bertujuan untuk menganalisis kinerja keuangan PT. Industri Jamu dan Farmasi Sido Muncul Tbk pada tahun 2016 hingga 2020 menggunakan analisis rasio keuangan. Penelitian ini menggunakan data laporan keuangan tahun 2020 dan dianalisis menggunakan empat rasio keuangan agar penelitian ini lebih lengkap dari penelitian sebelumnya. Metode penelitian yang digunakan untuk mengukur kinerja keuangan pada PT. Industri Jamu dan Farmasi Sido Muncul Tbk merupakan analisis rasio keuangan yang terdiri dari rasio likuiditas, rasio solvabilitas, rasio aktivitas dan rasio profitabilitas. Hasil penelitian ini berdasarkan rasio likuiditas yang diproksikan dengan current ratio dan cash ratio diketahui kondisi kinerja keuangan perusahaan dalam keadaan likuid. Rasio solvabilitas yang diproksikan dengan debt ratio dan debt to total equity ratio diketahui bahwa kondisi kinerja keuangan perusahaan dalam keadaan baik. Rasio aktivitas yang diproksikan dengan fixed asset turnover dan total asset turnover, bahwa kondisi kinerja keuangan perusahaan kurang efisien. Rasio profitabilitas yang 
diproksikan dengan return on asset baik dan return on invesment kurang baik. Rasio yang menunjukan indikasi yang bagus adalah rasio likuiditas dan rasio solvabilitas.

Kata Kunci: keuangan, likuiditas, solvabilitas, aktivitas, dan profitabilitas.

\section{PENDAHULUAN}

Kemunculan virus corona menjadi pukulan berat bagi perekonomian Indonesia. Himbauan physical distancing, bekerja dari rumah, belajar dan beribadah dari rumah, hingga larangan untuk mengadakan kegiatan yang menimbulkan kerumunan tentunya membuat roda ekonomi menjadi tersendat. Menurut (Rohmah \& Syari, 2020) hal ini dapat dilihat dari berbagai sisi 1). Perbankan. Bank Indonesia mengalami kerugian mencapai 40,165 trilyun disebabkan banyak modal asing yang memilih untuk hengkang. 2). APBN mengalami penurunan sebesar 2,5 \%. 3). Pariwisata. Menurut Bappenas penurunan devisa dari sektor pariwisata sebesar US\$530 juta. 4). Perhotelan Ketua Perhimpunan Hotel dan Restoran Indonesia (PHRI), Hariyadi B. Sukamdani wabah corona melanda menyebabkan penurunan omset hotel hingga $20 \%$. 5). Dari sektor penerbangan penurunan omset 207 milyar rupiah dikarenakan banyak penerbangan yang dibatalkan, dan bandara ditutup.

Virus corona yang semakin merebak juga mengguncang ekonomi global sektor pasar saham, surat utang, dan nilai emas. Selain itu untuk ekonomi dalam negeri juga terdampak dikarenakan sebagian besar transaksi ekspor-impor Indonesia berasal dari negara China (Burhanuddin \& Abdi, 2020). Selain dampak negatif tersebut, nyatanya corona juga membawa dampak positif yang memberikan keuntungan bagi perusahaan yang bergerak kesehatan dan kebersihan lingkungan. Beberapa diantaranya adalah perusahaan yang memproduksi masker, vitamin, obat-obatan, vaksin, dan disinfektan. Salah satu contoh perusahaan yang dapat meraup keuntungan pada masa pandemi adalah PT. Industri Jamu dan Farmasi Sido Muncul Tbk. Perusahaan ini bergerak dibidang industri barang konsumsi (consumer good) sub sektor obat-obatan. Selama pandemi produk-produknya diborong para pembeli. Hal tersebut terlihat dari kinerja produsen tolak angin ini sepanjang Kuartal I 2020 (Riksaning Ayu \& Supartoko, 2020).

Penilaian kinerja perusahaan dari segi keuangan dapat tercermin pada laporan keuangan yang dianalisis menjadi rasio keuangan yakni membandingkan pos keuangan satu dengan pos keuangan lainnya. Dalam penilaian kinerja keuangan perusahaan tingkat kesehatan perusahaan penting bagi pemegang saham karena menyangkut modal investasi yang bertujuan untuk mendapatkan tingkat hasil pengembalian yang menguntungkan. Bagi pihak manajemen perusahaan, penilaian kinerja ini berpengaruh untuk menyusunan rencana usaha perusahaan.

Penelitian ini mengkaji tentang pertumbuhan tingkat kinerja keuangan perusahaan PT Indutri Jamu dan Farmasi Sido Muncul Tbk. (SIDO) dengan menggunakan laporan keuangan tahun 2016 sampai tahun 2020 yang akan dianalisis menggunakan analisis rasio keuangan. Analisis rasio yang dipakai dalam penelitian ini meliputi analisis rasio likuiditas, solvabilitas, aktivitas dan profitabilitas. Dalam analisis rasio likuiditas menggunakan current ratio dan cash 
ratio. Analisis rasio solvabilitas menggunakan debt ratio dan debt to equity ratio. Analisis rasio aktivitas menggunakan fixed asset turnover dan total assets trunover. Analisis profitabilitas menggunakan return on asset dan return on investment.

\section{TINJAUAN LITERATUR}

\section{Laporan Keuangan}

Laporan keuangan suatu sumber informasi yang menggambarakan kondisi keuangan suatu perusahaan. Semakin baik kualitas laporan keuangan yang disajikan maka akan semakin menyakinkan pihak eksternal dalam melihat kinerja keuangan perusahaan tersebut. Berdasarkan definisi di atas dapat disimpulkan bahwa laporan keuangan adalah laporan yang digunakan untuk memperoleh informasi tentang kondisi keuangan suatu perusahaan dan hasil yang telah dicapai dalam satu periode tertentu (Marginingsih, 2017). Berbeda pendapat dengan (Tanor et al., 2015) yang menyebutkan bahwa laporan keuangan adalah hasil akhir dari proses akuntansi yang terkumpul dan disusun untuk digunakan sebagai laporan yang dapat memberi informasi kepada pengguna laporan keuangan dalam mengambil keputusan. Laporan keuangan yang lengkap terdiri dari komponen berikut : (1) Neraca, (2) Laporan laba/rugi, (3) Laporan perubahan modal, (4) Laporan arus kas, dan (5) Catatan atas laporan keuangan (Farda Eka Septiana, 2013).

\section{Analisis Laporan Keuangan}

Agar laporan keuangan menjadi lebih mudah dipahami dan dimengerti oleh berbagai pihak, perlu dilakukan analisa laporan keuangan. Tujuan utama dilakukan analisis laporan keuangan adalah agar bisa mengetahui posisi keuangan perusahaan saat ini (Kasmir, 2014). Jadi fungsi dari analisis laporan keuanagn adalah untukmengetahui posisi keuangan, secara mendalam, yang akan memperlihatkan apakah perusahaan telah mencapai target yang ditentukan. Hasil analisis laporan keuangan memberikan informasi tentang kelemahan dan kekuatan yang dimiliki oleh perusahaan. Dengan mengetahui kelemahan dan kekuatan, pihak manajemen dapat mengambil keputusan terkait dengan peningkatan kinerja perusahaan.

\section{Analisis Rasio Keuangan}

Rasio digunakan sebagai alat untuk membandingkan antara suatu jumlah dengan jumlah lainnya, kemudian hasil perbandingan nantinya akan ditemukan jawaban yang selanjutnya itu dijadikan bahan kajian untuk dianalisis dan diputuskan (Farda Eka Septiana, 2013). Analisis rasio keuangan adalah suatu metode analisis yang membandingkan antara pos laporan keuangan satu dengan pos lainnya untuk menilai kinerja perusahaan. Tujuan dari analisis rasio keuangan adalah untuk memahami informasi yang berasal dari laporan keuangan yang sifatnya terbatas. Dengan menggunakan rasio-rasio keuangan pihak internal maupun eksternal perusahaan akan memperoleh suatu informasi tentang kekuatan dan kelemahan perusahaan dari segi keuangan. Dari informasi tersebut, manajer dapat membuat keputusan yang menyangku kelangsungan perusahaan (Trianto, 2017). Rasio keuangan dimanfaatkan 
untuk mengevaluasi kondisi keuangan suatu perusahaan. Dengan membandingkan rasio perusahaan dari tahun ke tahun terlihat perubahan dan dapat ditentukan apakah terdapat kenaikan atau penurunan kondisi dan kinerja perusahaan dalam satu periode (Maulida et al., 2018).

\section{Jenis-Jenis Rasio Keuangan}

Dalam penelitian ini menggunakan rasio-rasio keuangan di bawah ini :

1. Rasio Likuiditas

Rasio likuiditas merupakan rasio yang menunjukkan kemampuan perusahaan dalam memenuhi kewajiban jangka pendek yang harus segera dipenuhi perusahaan (Marginingsih, 2017). Dalam penelitian ini rasio likuiditas yang digunakan adalah Current Ratio dan Cash Ratio. Current ratio merupakan rasio yang membandingkan antara aktiva lancar (current assets) dengan hutang lancar (current liabilities). Tingkat current ratio yang tinggi memberikan indikasi yang baik bagi kreditor jangka pendek. Hal ini karena perusahaan memiliki kemampuan untuk melunasi kewajiban-kewajiban finansial jangka pendeknya (Rhamadana \& Triyonowati, 2016). Cash ratio dapat dihitung dengan cara membandingkan antara kas yang ada diperusahaan (termasuk surat berharga dan deposito) dengan total hutang lancar. Rasio ini menilai kemampuan kas perusahaan untuk membayar hutang lancarnya tanpa harus mengubah aktiva lancar bukan kas (piutang dagang dan persediaan) menjadi kas (Masyitah E \& Kahar H, 2018).

2. Rasio Solvabilitas

Rasio solvabilitas atau disebut juga dengan rasio leverage. Rasio solvabilitas digunakan untuk mengukur sejauh mana aktiva perusahaan dibiayai oleh hutang (Tanor et al., 2015). Sedangkan menurut (Marginingsih, 2017) rasio solvabilitas digunakan untuk mengukur seluruh kewajiban perusahaan baik jangka panjang maupun jangka pendek. Dalam penelitian ini rasio solvabilitas yang digunakan adalah Debt Ratio dan Debt to Equity Ratio. Debt ratio (rasio hutang) dapat dihitung dengan cara membandingakan antara hutang (total debt) dengan total aset (total assets). Rasio ini berfungsi untuk mengukur berapa persen aset perusahaan yang dibiayai menggunakan hutang (Rhamadana \& Triyonowati, 2016). Debt to Equity Ratio (rasio total hutang terhadap modal sendiri) merupakan perbandingan total hutang yang dimiliki perusahaan dengan modal sendiri (ekuitas) (Rhamadana \& Triyonowati, 2016).

3. Rasio Aktivitas

Rasio aktivitas digunakan untuk mengukur efektivitas manajemen perusahaan dalam mengelola seluruh aset-asetnya. Rasio aktivitas menganalisis hubungan antara laporan laba rugi, khususnya penjualan, dengan unsur-unsur yang ada pada neraca, khususnya aktiva (Rhamadana \& Triyonowati, 2016). Dalam penelitian rasio aktiva yang digunakan adalah Fixed Asset Turn Over (Perputaran Aktiva Tetap) dan Total Assets 
Trunover (Perputaran Total Aktiva). Fixed Asset Turn Over merupakan rasio yang digunakan untuk mengukur kemampuan perusahaan dalam mengelola aset tetapnya. Atau dengan kata lain, untuk mengukur apakah perusahaan sudah menggunakan kapasitas aktiva tetap sepenuhnya atau belum (Rhamadana \& Triyonowati, 2016). Total assets trunover (TATO) mengukur kemampuan perusahaan dalam mengelola total aset. Total assets turnover dihitung dari pembagian antara penjualan dengan total asetnya (Rhamadana \& Triyonowati, 2016).

4. Rasio Profitabilitas

Rasio profitabilitas adalah rasio yang mengukur kemampuan perusahaan untuk menghasilkan keuntungan dengan menggunakan modal yang tertanam dalam perusahaan (Suhendro, 2017). Berbeda dengan (Erica, 2018) rasio profitabilitas adalah rasio untuk kemampuan mencari keuntungan atau laba dalam satu periode. Dalam penelitian ini rasio profitabilitas yang digunakan adalah Return on Assets (ROA) dan Return on Invesment (ROI). Return on assets (ROA) merupakan digunakan mengukur kemampuan perusahaan menghasilkan laba dari total aktiva yang digunakan. Aktiva yang dimaksud adalah keseluruhan harta perusahaan, yang diperoleh dari modal sendiri maupun dari modal asing yang telah diubah perusahaan menjadi aktiva-aktiva perusahaan yang digunakan untuk kelangsungan hidup perusahaan (Yusuf, 2017). Return on investment (ROI) merupakan rasio yang menunjukkan kemampuan perusahaan menghasilkan labadari modal yang ditanamkan. Rasio ini merupakan salah satu indikator dari rasio profitabilitas (Sajiyah, 2016).

\section{METODE PENELITIAN}

\section{Jenis Penelitian}

Penelitian ini adalah jenis penelitian kuantitatif yang menggunakan studi deskriptif, yaitu penelitian yang merumuskan dan menafsirkan data yang ada sehingga memberikan gambaran yang jelas melalui pengumpulan, penyusunan dan menganalisis data sehingga dapat diketahui gambaran umum obyek yang diteliti (Rhamadana \& Triyonowati, 2016).

\section{Populasi dan Sampel}

Adapun objek dalam penelitian ini adalah perusahaan yang bergerak dibidang industri barang konsumsi (consumer good) sub sektor obat-obatan yaitu PT Indutri Jamu dan Farmasi Sido Muncul Tbk. (SIDO). Sampel penelitian ini dilakukan dengan purposive sampling yaitu pengambilan sampel secara sengaja sesuai dengan persyaratan yang diperlukan. Data diambil dari www.idx.com laporan keuangan tahun 2016 sampai 2020 PT Industri Jamu dan Farmasi Sido Muncul Tbk. (SIDO) dan akan dianalisis menggunakan rasio likuiditas, solvabilitas, aktivitas, dan profitabilitas. 


\section{Teknik Analisis Data}

Penelitian ini menggunakan teknik analisis data metode kuantitatif, yaitu analisis data yang menggunakan angka-angka ke dalam analisis rasio keuangan untuk membandingkan kinerja keuangan perusahaan dari tahun ke tahun. Adapun teknik analisis yang digunakan dalam penelitian ini adalah sebagai berikut :

1. Menggunakan rasio keuangan yang terdiri dari :

Tabel 1. Pengukuran Variabel

\begin{tabular}{|c|c|c|}
\hline No. & Nama Variabel & Pengukuran \\
\hline a. & Rasio Likuiditas & $\begin{array}{l}\text { Current Ratio }=\frac{\text { Aktiva Lancar }}{\text { Hutang Lancar }} \times 100 \% \\
\text { Cash Ratio }=\frac{\text { Cas }+ \text { Setara Kas }}{\text { Hutang Lancar }} \times 100 \%\end{array}$ \\
\hline b. & $\begin{array}{l}\text { Rasio } \\
\text { Solvabilitas }\end{array}$ & Debt Ratio $=\frac{\text { Total Hutang }}{\text { Total Aktifa }} \times 100 \%$ \\
\hline & & Debt to Equity Ratio $=\frac{\text { Total Hutang }}{\text { Total Modal }} \times 100 \%$ \\
\hline c. & Rasio Aktivitas & Fixed Asset Turnover $=\frac{\text { Penjualan }}{\begin{array}{c}\text { Aktiva Tetap } \\
\text { Penjualan }\end{array}} \times 1$ \\
\hline & & Total Asset Turnover $=\frac{\text { Total Aktiva }}{\text { Tol }} \times 1$ \\
\hline \multirow[t]{2}{*}{ d. } & $\begin{array}{l}\text { Rasio } \\
\text { Profitahilitas }\end{array}$ & Return on Asset $=\frac{\text { EB I }}{\text { Total Aktiva }} \times 100 \%$ \\
\hline & & Return on Investmen $=\frac{\text { EAT }}{\text { Total Modal }} \times 100 \%$ \\
\hline
\end{tabular}

2. Mengklasifikasikan kesehatan rasio keuangan

Setelah perhitungan rasio keuangan maka akan dibandingkan dengan standar industri rasio keuangan. Berikut ini adalah standar rasio keuangan industri :

Tabel 2. Standar Rasio Keuangan Industri

\begin{tabular}{ll}
\hline Rasio & Standar industri \\
\hline Current Ratio & $200 \%$ \\
Cash Ratio & $50 \%$ \\
Debt Ratio & $35 \%$ \\
Debt to Equity Ratio & $90 \%$ \\
Fixed Asset Turnover & 2 kali \\
Total Asset Turnover & $5 \mathrm{kali}$ \\
Return on Assets & $30 \%$ \\
Return on Investment & $30 \%$ \\
\hline
\end{tabular}

Sumber :(Lithfiyah et al., 2019) dan (Kurnia Rinda, 2020) 


\section{HASIL DAN PEMBAHASAN}

\section{Rasio Likuiditas}

Rasio likuiditas yang diperhitungkan dalam penelitian ini adalah sebagai berikut :

1. Current Ratio

Current ratio merupakan rasio keuangan yang mengukur likuiditas keuangan perusahaan dengan cara membandingkan antara aktiva-aktiva lancar (current assets) dengan hutang lancar (current liabilities). Semakin tinggi current ratio mengindikasi jaminan yang baik bagi kreditor jangka pendek karena perusahaan mampu membayar kewajiban hutang jangka pendeknya. Berikut ini disajikan perhitungan current ratio PT Indutri Jamu dan Farmasi Sido Muncul Tbk. (SIDO) tahun 2016 sampai tahun 2020 :

Table 3. Current Ratio PT Indutri Jamu dan Farmasi Sido Muncul Tbk. (SIDO) tahun 2016 sampai tahun 2020

\begin{tabular}{llllll}
\hline Tahun & $\begin{array}{l}\text { Aktiva } \\
\text { Lancar } \\
\text { (Rp) }\end{array}$ & $\begin{array}{l}\text { Hutang } \\
\text { Lancar } \\
(\mathbf{R p})\end{array}$ & $\begin{array}{l}\text { Current } \\
\text { Ratio } \\
\mathbf{( \% )}\end{array}$ & $\begin{array}{l}\text { Standar } \\
\text { Industri } \\
(\mathbf{\%})\end{array}$ & Kategori \\
\hline 2016 & 1.794 .125 & 215.686 & 831,82 & 200 & Likuid \\
2017 & 1.628 .901 & 208.507 & 781,22 & 200 & Likuid \\
2018 & 1.504 .150 & 240.687 & 624,94 & 200 & Likuid \\
2019 & 1.716 .235 & 416.211 & 412,35 & 200 & Likuid \\
2020 & 2.052 .081 & 560.043 & 366,41 & 200 & Likuid \\
\hline \multicolumn{2}{l}{ Rata-rata current ratio } & & 603,35 & & \\
\hline
\end{tabular}

Sumber : Data sekunder diolah 2020

Dengan demikian dapat diketahui selama tahun 2016-2020 rata-rata current ratio PT Indutri Jamu dan Farmasi Sido Muncul Tbk. (SIDO) sebesar 603,35\% artinya setiap Rp 1 hutang lancar dijamin oleh aktiva lancar sebesar Rp 603,35. Pada Tabel 2 dimana current ratio PT Indutri Jamu dan Farmasi Sido Muncul Tbk. (SIDO) setiap tahun mengalami penurunan walau begitu setiap tahunnya current ratio menunjukan keadaan keuangan yang likuid dan berada diatas standar industri yakni sebesar $200 \%$.

2. Cash Ratio

Rasio ini menilai kemampuan kas perusahaan untuk melunasi hutang lancarnya tanpa harus menguba aktiva lancar bukan kas (piutang dagang dan persediaan) menjadi kas. Berikut ini disajikan perhitungan cash ratio PT Indutri Jamu dan Farmasi Sido Muncul Tbk. (SIDO) tahun 2016 sampai tahun 2020 : 
Table 4. Cash Ratio PT Indutri Jamu dan Farmasi Sido Muncul Tbk. (SIDO) tahun 2016 sampai tahun 2020

\begin{tabular}{llllll}
\hline Tahun & $\begin{array}{l}\text { Kas Setara } \\
\text { Kas } \\
(\mathbf{R p})\end{array}$ & $\begin{array}{l}\text { Hutang } \\
\text { Lancar } \\
\mathbf{( R p )}\end{array}$ & $\begin{array}{l}\text { Cash Ratio } \\
(\mathbf{\%})\end{array}$ & $\begin{array}{l}\text { Standar } \\
\text { Industri } \\
(\%)\end{array}$ & Kategori \\
\hline 2016 & 997.135 & 215.686 & 462,31 & 50 & Likuid \\
2017 & 902.852 & 208.507 & 433,01 & 50 & Likuid \\
2018 & 873.512 & 240.687 & 362,92 & 50 & Likuid \\
2019 & 864.824 & 416.211 & 207,78 & 50 & Likuid \\
2020 & 1.031 .954 & 560.043 & 204,74 & 50 & Likuid \\
\hline \multicolumn{5}{l}{ Rata-rata cash ratio } \\
\hline
\end{tabular}

Sumber: Data sekunder diolah 2020

Dengan demikian dapat diketahui selama tahun 2016-2020 rata-rata cash ratio PT Indutri Jamu dan Farmasi Sido Muncul Tbk. (SIDO) sebesar 334,15\% artinya setiap Rp 1 hutang lancar dijamin oleh kas dan setara kas sebesar Rp 334,15. Pada Tabel 3 dimana cash ratio PT Indutri Jamu dan Farmasi Sido Muncul Tbk. (SIDO) setiap tahun mengalami penurunan setiap tahunnya namun cash ratio menunjukan keadaan keuangan yang likuid dan berada diatas standar industri yakni sebesar $50 \%$.

\section{Rasio Solvabilitas}

Rasio solvabilitas yang diperhitungkan dalam penelitian ini adalah sebagai berikut :

1. Debt Ratio

Debt ratio (rasio hutang) merupakan rasio hutang mengukur berapa persen aset perusahaan yang dibelanjai dengan hutang. Semakin rendah debt ratio menunjukan kinerja yang baik bagi perusahaan. Berikut ini disajikan perhitungan debt ratio PT Indutri Jamu dan Farmasi Sido Muncul Tbk. (SIDO) tahun 2016 sampai tahun 2020 :

Table 5. Debt Ratio PT Indutri Jamu dan Farmasi Sido Muncul Tbk. (SIDO) tahun 2016 sampai tahun 2020

\begin{tabular}{llllll}
\hline Tahun & $\begin{array}{l}\text { Total } \\
\text { Hutang } \\
(\mathbf{R p})\end{array}$ & $\begin{array}{l}\text { Total Aktiva } \\
\mathbf{( R p )}\end{array}$ & $\begin{array}{l}\text { Debt Ratio } \\
\mathbf{( \% )}\end{array}$ & $\begin{array}{l}\text { Standar } \\
\text { Industri } \\
(\mathbf{\%})\end{array}$ & Kategori \\
\hline 2016 & 215.686 & 2.987 .614 & 7,22 & 35 & Baik \\
2017 & 208.507 & 3.158 .198 & 6,60 & 35 & Baik \\
2018 & 240.687 & 3.237 .220 & 7,43 & 35 & Baik \\
2019 & 472.191 & 3.536 .898 & 13,35 & 35 & Baik \\
2020 & 627.776 & 3.849 .516 & 16,30 & 35 & Baik \\
\hline \multicolumn{7}{l}{ Rata-rata debt ratio } & & 10,18 & & \\
\hline
\end{tabular}

Sumber : Data sekunder diolah 2020 
Dengan demikian dapat diketahui selama tahun 2016-2020 rata-rata debt ratio PT Indutri Jamu dan Farmasi Sido Muncul Tbk. (SIDO) sebesar 10,18\% artinya aktiva sebesar $10,18 \%$ berasal dari hutang. Namun dapat dilihat pada Tabel 4 dimana debt ratio PT Indutri Jamu dan Farmasi Sido Muncul Tbk. (SIDO) setiap tahun mengalami peningkatan walaupun setiap tahunnya masuk kategori baik karena debt ratio kurang dari standar industri yakni sebesar $35 \%$.

2. Debt to Equity Ratio

Debt to Equity Ratio (rasio total hutang terhadap modal sendiri) merupakan perbandingan total hutang yang dimiliki perusahaan dengan modal sendiri Semakin rendah debt to equity ratio menunjukan kinerja yang baik bagi perusahaan. Pada tahun 2016-2020 rata-rata debt to equity ratio PT Indutri Jamu dan Farmasi Sido Muncul Tbk. (SIDO) sebesar $11,48 \%$ artinya modal sebesar $11,48 \%$ berasal dari hutang. Namun dapat dilihat pada Tabel 5 dimana debt ratio PT Indutri Jamu dan Farmasi Sido Muncul Tbk. (SIDO) setiap tahun mengalami peningkatan walaupun setiap tahunnya masuk kategori baik karena debt ratio kurang dari standar industri yakni sebesar $90 \%$. Berikut ini disajikan perhitungan debt to equity ratio PT Indutri Jamu dan Farmasi Sido Muncul Tbk. (SIDO) tahun 2016 sampai tahun 2020 :

Table 6. Debt to Equity Ratio PT Indutri Jamu dan Farmasi Sido Muncul Tbk. (SIDO) tahun 2016 sampai tahun 2020

\begin{tabular}{llllll}
\hline Tahun & $\begin{array}{l}\text { Total } \\
\text { Hutang } \\
(\mathbf{R p})\end{array}$ & $\begin{array}{l}\text { Total Modal } \\
\mathbf{( R \mathbf { p } )}\end{array}$ & $\begin{array}{l}\text { Debt Ratio } \\
\mathbf{( \% )}\end{array}$ & $\begin{array}{l}\text { Standar } \\
\text { Industri } \\
(\%)\end{array}$ & Kategori \\
\hline 2016 & 215.686 & 2.757 .885 & 7,82 & 90 & Baik \\
2017 & 208.507 & 2.895 .865 & 7,20 & 90 & Baik \\
2018 & 240.687 & 2.953 .272 & 8,14 & 90 & Baik \\
2019 & 472.191 & $3.064,707$ & 15,40 & 90 & Baik \\
2020 & 627.776 & 3.221 .740 & 19,48 & 90 & Baik \\
\hline \multicolumn{7}{l}{ Rata-rata debt to equity ratio } \\
\hline
\end{tabular}

Sumber : Data sekunder diolah 2020

\section{Rasio Aktivitas}

Rasio aktivitas yang diperhitungkan dalam penelitian ini adalah sebagai berikut :

1. Fixed Assets Turnover

Fixed asset turnover merupakan rasio yang digunakan untuk mengukur berapa kali dana yang ditanamkan dalam aktiva tetap berputar dalam satu periode. Berikut ini disajikan perhitungan fixed assets turnover PT Indutri Jamu dan Farmasi Sido Muncul Tbk. (SIDO) tahun 2016 sampai tahun 2020 : 
Table 7. Fixed Assets Turnover PT Indutri Jamu dan Farmasi Sido Muncul Tbk.

(SIDO) tahun 2016 sampai tahun 2020

\begin{tabular}{llllll}
\hline Tahun & $\begin{array}{l}\text { Penjualan } \\
\text { (Rp) }\end{array}$ & $\begin{array}{l}\text { Aktiva Tetap } \\
\text { (Rp) }\end{array}$ & $\begin{array}{l}\text { Fixed } \\
\text { Assets } \\
\text { Turnover }\end{array}$ & $\begin{array}{l}\text { Standar } \\
\text { Industri } \\
\text { (kali) }\end{array}$ & Kategori \\
\hline 2016 & 2.561 .806 & 1.051 .227 & 2,4 & 2 & Baik \\
2017 & 2.573 .840 & 1.215 .176 & 2,1 & 2 & Baik \\
2018 & 1.944 .223 & 1.491 .225 & 1,3 & 2 & Kurangefisien \\
2019 & 3.067 .434 & 1.820 .663 & 1,6 & 2 & Kurang efisien \\
2020 & 3.335 .411 & 1.797 .435 & 1,8 & 2 & Kurang efisien \\
\hline \multicolumn{7}{c}{ Rata-rata fixed asset turnover } & 1,84 & \\
\hline \multicolumn{7}{c}{ Sumber: Data sekunder diolah 2020 }
\end{tabular}

Dengan demikian dapat diketahui selama tahun 2016-2020 rata-rata fixed assets turnover PT Indutri Jamu dan Farmasi Sido Muncul Tbk. (SIDO) sebesar 1,84 kali artinya perusahaan hanya mampu menghasilkan penjualan sebesar 1,84 kali dari aktiva tetap. Pada Tabel 6 dimana fixed assets turnover PT Indutri Jamu dan Farmasi Sido Muncul Tbk. (SIDO) setiap tahun mengalami penurunan. Pada tahun 2016 dan 2017 masuk kategori baik karena diatas ratarata industri yakni sebesar 2 kali, namun untuk tahun 2018, 2019, dan 2020 masuk kategori kurang efisien karena kurang dari standar industri tapi sudah terlihat ada peningkatan penjualan dari tahun 2018 sampai 2020 walaupun masih dibawah standar industri yakni 2 kali.

\section{Total Assets Turnover}

Total assets trunover (TATO) mengukur perputaran dari semua aset yang dimiliki perusahaan. Total assets turnover dihitung dari pembagian antara penjualan dengan total asetnya. Berikut ini disajikan perhitungan total assets turnover PT Indutri Jamu dan Farmasi Sido Muncul Tbk. (SIDO) tahun 2016 sampai tahun 2020 :

Table 8. Total Assets Turnover PT Indutri Jamu dan Farmasi Sido Muncul Tbk. (SIDO) tahun 2016 sampai tahun 2020

\begin{tabular}{|c|c|c|c|c|c|}
\hline Tahun & $\begin{array}{l}\text { Penjualan } \\
\text { (Rp) }\end{array}$ & $\begin{array}{l}\text { Total } \\
\text { Aktiva } \\
\text { (Rp) }\end{array}$ & $\begin{array}{l}\text { Total Assets } \\
\text { Turnover } \\
\text { (kali) }\end{array}$ & $\begin{array}{l}\text { Standar } \\
\text { Industri } \\
\text { (kali) }\end{array}$ & Kategori \\
\hline 2016 & 2.561 .806 & 2.987 .614 & 0,8 & 5 & Kurang efisien \\
\hline 2017 & 2.573 .840 & 3.158 .198 & 0,8 & 5 & Kurang efisien \\
\hline 2018 & 1.944 .223 & 3.237 .220 & 0,6 & 5 & Kurang efisien \\
\hline 2019 & 3.067 .434 & 3.536 .898 & 0,8 & 5 & Kurang efisien \\
\hline 2020 & 3.335.411 & 3.849 .516 & 0,8 & 5 & Kurang efisien \\
\hline
\end{tabular}

Sumber : Data sekunder diolah 2020 
Dengan demikian dapat diketahui selama tahun 2016-2020 rata-rata total assets turnover PT Indutri Jamu dan Farmasi Sido Muncul Tbk. (SIDO) sebesar 0,76 kali artinya perusahaan hanya mampu menghasilkan penjualan sebesar 0,76 kali dari total aktiva. Namun dapat dilihat pada Tabel 7 dimana total assets turnover PT Indutri Jamu dan Farmasi Sido Muncul Tbk. (SIDO) setiap tahun mengalami stagnan bahkan menurun pada tahun 2018 dan masuk kategori kurang efisien karena masih dibawah standar industri yakni 5 kali.

\section{Rasio Profitabilitas}

Rasio aktivitas yang diperhitungkan dalam penelitian ini adalah sebagai berikut :

1. Return on Assets (ROA)

Return on assets (ROA) mampu mengukur kemampuan perusahaan menghasilkan laba dari total aktiva. Aktiva yang dimaksud adalah jumlah keseluruhan harta perusahaan, yang dibeli dari modal sendiri maupun dari modal asing. Semakin tinggi rasio ROA maka menunjukan kinerja perusahaan yang bagus. Pada tahun 2016-2020 rata-rata return on assets PT Indutri Jamu dan Farmasi Sido Muncul Tbk. (SIDO) sebesar 32,91\% artinya perusahaan mampu menghasilkan laba sebelum pajak sebesar 32,91\% dari total aktiva. Namun dapat dilihat pada Tabel 8 dimana return on assets PT Indutri Jamu dan Farmasi Sido Muncul Tbk. (SIDO) setiap tahun mengalami fluktuasi dengan ROA paling tinggi di tahun 2016 dan paling rendah di tahun 2019. Return on assets PT Indutri Jamu dan Farmasi Sido Muncul Tbk. (SIDO) masuk kategori baik karena berada diatas standar industri yakni sebesar $30 \%$. Berikut ini disajikan perhitungan return on assets PT Indutri Jamu dan Farmasi Sido Muncul Tbk. (SIDO) tahun 2016 sampai tahun 2020 :

Table 9. Return on Assets PT Indutri Jamu dan Farmasi Sido Muncul Tbk. (SIDO) tahun 2016 sampai tahun 2020

\begin{tabular}{llllll}
\hline Tahun & $\begin{array}{l}\text { EBIT } \\
(\mathbf{R p})\end{array}$ & $\begin{array}{l}\text { Total Aktiva } \\
(\mathbf{R p})\end{array}$ & $\begin{array}{l}\text { Return on } \\
\text { Assets (\%) }\end{array}$ & $\begin{array}{l}\text { Standar } \\
\text { Industri } \\
(\%)\end{array}$ & Kategori \\
\hline 2016 & 1.067 .664 & 2.987 .614 & 35,73 & 30 & Baik \\
2017 & 1.161 .959 & 3.158 .198 & 36,79 & 30 & Baik \\
2018 & 987.190 & 3.237 .220 & 30,49 & 30 & Baik \\
2019 & 1.073 .835 & 3.536 .898 & 30,36 & 30 & Baik \\
2020 & 1.199 .548 & 3.849 .516 & 31,16 & 30 & Baik \\
\hline \multicolumn{5}{c}{ Rata-rata return on assets } \\
\hline \multicolumn{5}{c}{ Sumber : Data sekunder diolah 2020 }
\end{tabular}

2. Return on Invesment (ROI)

Return on investment (ROI) merupakan rasio yang menunjukkan perbandingan antara laba setelah pajak dengan total modal. Rasio ini mengukur kemampuan perusahaan menghasilkan laba bersih setelah pajak dari total modal yang digunakan. Semakin tinggi 
rasio ROI maka menunjukan kinerja perusahaan yang bagus. Berikut ini disajikan perhitungan return on investment PT Indutri Jamu dan Farmasi Sido Muncul Tbk. (SIDO) tahun 2016 sampai tahun 2020 :

Table 9. Return on Investment PT Indutri Jamu dan Farmasi Sido Muncul Tbk.

(SIDO) tahun 2016 sampai tahun 2020

\begin{tabular}{llllll}
\hline Tahun & $\begin{array}{l}\text { EAT } \\
(\mathbf{R p})\end{array}$ & $\begin{array}{l}\text { Total Modal } \\
(\mathbf{R p})\end{array}$ & $\begin{array}{l}\text { Return on } \\
\text { Investment } \\
(\mathbf{\%})\end{array}$ & $\begin{array}{l}\text { Standar } \\
\text { Industri } \\
(\%)\end{array}$ & Kategori \\
\hline 2016 & 480.525 & 2.757 .885 & 17 & 30 & Kurang efisien \\
2017 & 533.799 & 2.895 .865 & 18 & 30 & Kurang efisien \\
2018 & 663.849 & 2.953 .272 & 22 & 30 & Kurang efisien \\
2019 & 807.689 & $3.064,707$ & 26 & 30 & Kurang efisien \\
2020 & 934.016 & 3.221 .740 & 28 & 30 & Kurang efisien \\
\hline \multicolumn{6}{l}{} \\
\hline
\end{tabular}

Sumber : data sekunder diolah 2020.

Dengan demikian dapat diketahui selama tahun 2016-2020 rata-rata return on invesment (ROI) PT Indutri Jamu dan Farmasi Sido Muncul Tbk. (SIDO) sebesar 22,2\% artinya perusahaan mampu menghasilkan laba setelah pajak sebesar $22,2 \%$ dari total modal. Namun dapat dilihat pada Tabel 9 dimana return on invesment PT Indutri Jamu dan Farmasi Sido Muncul Tbk. (SIDO) setiap tahun mengalami peningkatan dengan ROI namun masuk kategori kurang efisien karena belum mampu melampaui standar industri yakni sebesar $30 \%$.

\section{KESIMPULAN}

Berdasarkan dari hasil analisis data pada penelitin ini maka penliti mengambil kesimpulan sebagai berikut :

1. Analisis kinerja keuangan perusahaan dengan menggunakan current ratio pada PT Indutri Jamu dan Farmasi Sido Muncul Tbk. (SIDO) tahun 2016- 2020, setiap tahun mencapai standar industri yang ditetapkan yakni 200\% sehingga masuk kategori likuid.

2. Analisis kinerja keuangan perusahaan dengan menggunakan cash ratio pada PT Indutri Jamu dan Farmasi Sido Muncul Tbk. (SIDO) tahun 2016-2020, setiap tahun mencapai standar industri yang ditetapkan yakni 50\% sehingga masuk kategori likuid.

3. Analisis kinerja keuangan perusahaan dengaan menggunakan debt ratio pada PT Indutri Jamu dan Farmasi Sido Muncul Tbk. (SIDO) tahun 2016-2020, setiap tahun tidak melebihi standar industri yang ditetapkan yakni maksimal 35\% sehingga masuk kategori baik.

4. Analisis kinerja keuangan perusahaan dengaan menggunakan debt to equity ratio pada PT Indutri Jamu dan Farmasi Sido Muncul Tbk. (SIDO) tahun 2016-2020, setiap tahun tidak melebihi standar industri yang ditetapkan yakni maksimal $90 \%$ sehingga masuk kategori baik. 
5. Analisis kinerja keuangan perusahaan dengaan menggunakan fixed asset turnover pada PT Indutri Jamu dan Farmasi Sido Muncul Tbk. (SIDO) tahun 2016-2020, pada tahun 2016 dan 2017 mampu mencapai standar industri yakni 2 kali sehingga masuk kategori baik, namun pada tahun 2018 sampai 2020 belum mampu mencapai standar industri yang ditetapkan sehingga masuk kategori kurang efisien.

6. Analisis kinerja keuangan perusahaan dengaan menggunakan total asset turnover pada PT Indutri Jamu dan Farmasi Sido Muncul Tbk. (SIDO) tahun 2016-2020, pada tahun 2016 dan 2020 belum mampu mencapai standar industri yakni 5 kali sehingga masuk kategori kurang efisien.

7. Analisis kinerja keuangan perusahaan dengaan menggunakan return on assets pada PT Indutri Jamu dan Farmasi Sido Muncul Tbk. (SIDO) tahun 2016-2020, pada tahun 2016 dan 2020 mampu mencapai standar industri yakni 30\% sehingga masuk kategori baik.

8. Analisis kinerja keuangan perusahaan dengaan menggunakan return on investment pada PT Indutri Jamu dan Farmasi Sido Muncul Tbk. (SIDO) tahun 2016-2020, pada tahun 2016 dan 2020 mampu mencapai standar industri yakni 30\% sehingga masuk kategori baik.

\section{REFERENSI}

Burhanuddin, C. I., \& Abdi, M. N. (2020). Ancaman Krisis Ekonomi Global dari Dampak Penyebaran Virus Corona (Covid 19). Akmen, 17(1), 90-98.

Erica, D. (2018). Analisa Rasio Laporan Keuangan Untuk Menilai Kinerja Perusahaan PT Kino Indonesia Tbk. Ecodemica, 2(1), 117-124.

Farda Eka Septiana, A. W. (2013). Pengaruh Rasio Keuangan Terhadap Return Saham Pada Perusahaan Manufaktur. Journal of Chemical Information and Modeling, 5, 1-21.

Kasmir. (2014). Analisis Laporan Keuangan . Edisi (Pertama). PT. Raja Grafindo Persada.

Kurnia Rinda. (2020). Analisis Akuisisi PerusahaanTerhadap Kinerja Keuangan. Jurnal Akuntansi Indonesia, 16(1), 24-34.

Lithfiyah, E., Irwansyah, \& Fitria Yunita. (2019). Analisis rasio keuangan. Akuntabel, 16(2), 189196.

Marginingsih, R. (2017). Penilaian Kinerja Perusahaan Dengan Menggunakan Analisa Rasio Keuangan Pada Perusahaan Telekomunikasi di Indonesia. Cakrawala - Jurnal Humaniora, 15(1), 15.

Masyitah E \& Kahar H. (2018). Analisis Kinerja Keuangan Menggunakan Rasio Likuiditas dan Profitabilitas Emi. Jurnal Akuntansi dan Keuangan Kontemporer, 14(1), 6.

Maulida, indira S., Moehaditoyo, S. H., \& Nugroho, M. (2018). Financial Ratio Analysis For Predicting Financial Distress in Manufacturing Companies Listed in Indonesia Stock Exchange. Jurnal IImiah Administrasi Bisnis dan Inovasi, 2(1), 179-193.

Rhamadana, R. bima, \& Triyonowati. (2016). Analisis Rasio Keuangan untuk Menilai Kinerja Keuangan pada PT . H . M Sampoerna Tbk. Jurnal Imu dan Riset Manajemen, 5(7).

Riksaning Ayu, K., \& Supartoko, B. (2020). Strategi Perusahaan Sido Muncul dalam Pengembangan Kegiatan Corporate Social Responsibility. Warta ISKI, 3(01), 1-12.

Rohmah, S. N., \& Syari, F. (2020). Adakah Peluang Bisnis di Tengah Kelesuan Perekonomian Akibat Pandemi Corona Virus Covid-19 ? 'Adalah ; Buletin Hukum \& Keadilan, 4(1).

Sajiyah, I. (2016). Pengaruh Current Ratio, Debt to Equity, dan Return on Investment Terhadap 
Harga Saham Perusahaan Food \&Beverage. Akademika, 14(1), 32-39.

Suhendro, D. (2017). Analisis Profitabilitas dan Likuiditas untuk Menilai Kinerja Keuangan pada PT Siantar Top Tbk. Jurnal ekonomi dan bisnis Islam, 4(2), 218-235.

Tanor, M. O., Sabijono, H., \& Walandouw, S. K. (2015). Analisis Laporan Keuangan dalam Mengukur Kinerja Keuangan Pada. Jurnal Ekonomi dan Bisnis, 3(3), 639-649.

Trianto, A. (2017). Analisis Laporan Keuangan Sebagai Alat untuk Menilai Kinerja Keuangan Perusahaan Pada Pt. Bukit Asam (Persero) Tbk Tanjung Enim. IImiah Ekonomi Global Masa Kini, 8(03), 1-10.

Yusuf, M. (2017). Dampak Indikator Rasio Keuangan terhadap Profitabilitas Bank Umum Syariah di Indonesia. Jurnal Keuangan dan Perbankan : ISSN 1829-9865, 13(2), 141-151. 